Public Policy and Politics

Series Editors: Colin Fudge and Robin Hambleton

Public policy-making in western democracies is confronted by new pressures. Central values relating to the role of the state, the role of markets and the role of citizenship are now all contested and the consensus built up around the Keynesian welfare state is under challenge. New social movements are entering the political arena; electronic technologies are transforming the nature of employment; changes in demographic structure are creating heightened demands for public services; unforeseen social and health problems are emerging; and, most disturbing, social and economic inequalities are increasing in many countries.

How governments - at international, national and local levels - respond to this developing agenda is the central focus of the Public Policy and Politics series. Aimed at a student, professional, practitioner and academic readership, it aims to provide up-to-date, comprehensive and authoritative analyses of public policy-making in practice.

The series is international and interdisciplinary in scope, and bridges theory and practice by relating the substance of policy to the politics of the policymaking process. 


\section{Public Policy and Politics}

Series Editors: Colin Fudge and Robin Hambleton

\section{PUBLISHED}

Kate Ascher, The Politics of Privatisation: Contracting Out Public Services

Rob Atkinson and Graham Moon, Urban Politics in Britain: The City, the State and the Market

Jacqueline Barron, Gerald Crawley and Tony Wood, Councillors in Crisis: The Public and Private Worlds of Local Councillors

Danny Burns, Robin Hambleton and Paul Hoggett, The Politics of Decentralisation: Revitalising Local Democracy

Aram Eisenschitz and Jamie Gough, The Politics of Local Economic Policy:

The Problems and Possibilities of Local Initiative

Stephen Glaister, June Burnham, Handley Stevens and Tony Travers, Transport Policy in Britain

Christopher Ham, Health Policy in Britain: The Politics and Organisation of the National Health Service (fourth edition)

Ian Henry, The Politics of Leisure Policy

Peter Malpass and Alan Murie, Housing Policy and Practice (fifth edition)

Robin Means and Randall Smith, Community Care: Policy and Practice (second edition)

Gerry Stoker, The Politics of Local Government (second edition)

Kieron Walsh, Public Services and Market Mechanisms: Competition, Contracting and the New Public Management

\section{FORTHCOMING}

Tony Green and Geoff Whitty, The Changing Politics of Education:

Education Policy in Contemporary Britain

John Solomos, Racial Inequality and Public Policy

\section{Public Policy and Politics}

Series Standing Order

ISBN 978-0-333-71705-9 hardcover

ISBN 978-0-333-69349-0 paperback

(outside North America only)

You can receive future titles in this series as they are published. To place a standing order please contact your bookseller or, in the case of difficulty, write to us at the address below with your name and address, the title of the series and the ISBNs quoted above.

Customer Services Department, Macmillan Distribution Ltd Houndmills, Basingstoke, Hampshire RG21 6XS, England. 


\title{
Health Policy in Britain
}

\section{The Politics and Organisation of the National Health Service}

\author{
Fourth Edition
}

Christopher Ham

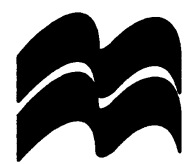


Christopher Ham 1982, 1985, 1992, 1999

Softcover reprint of the hardcover 4th edition 1999 978-0-333-76406-0

All rights reserved. No reproduction, copy or transmission of this publication may be made without written permission.

No paragraph of this publication may be reproduced, copied or transmitted save with written permission or in accordance with the provisions of the Copyright, Designs and Patents Act 1988, or under the terms of any licence permitting limited copying issued by the Copyright Licensing Agency, 90 Tottenham Court Road, London W1P 0LP.

Any person who does any unauthorised act in relation to this publication may be liable to criminal prosecution and civil claims for damages.

The author has asserted his right to be identified as the author of this work in accordance with the Copyright, Designs and Patents Act 1988.

First edition 1982

Second edition 1985

Third edition 1992

Fourth edition 1999

Published by

MACMILLAN PRESS LTD

Houndmills, Basingstoke, Hampshire RG21 6XS

and London

Companies and representatives

throughout the world

ISBN 978-0-333-76407-7 ISBN 978-1-349-27706-3 (eBook) DOI 10.1007/978-1-349-27706-3

A catalogue record for this book is available from the British Library.

$\begin{array}{llllllllll}10 & 9 & 8 & 7 & 6 & 5 & 4 & 3 & 2 & 1\end{array}$

$\begin{array}{rrrrrrrrrr}08 & 07 & 06 & 05 & 04 & 03 & 02 & 01 & 00 & 99\end{array}$

Copy-edited and typeset by Povey-Edmondson

Tavistock and Rochdale, England 


\section{To Ioanna}




\section{Contents}

List of Figures and Tables

Acknowledgements

xii

Preface to the Fourth Edition xiii

Abbreviations $\quad$ xiv

Introduction

1 The Development of Health Services and Health Policy 4 $\begin{array}{ll}\text { Public health services } & 5\end{array}$

Mothers and young children $\quad 6$

$\begin{array}{ll}\text { Health insurance } & 7\end{array}$

$\begin{array}{lr}\text { Hospital services } & 8\end{array}$

The establishment of the National Health Service $\quad 10$

The structure of the National Health Service 12

$\begin{array}{ll}\text { The NHS between } 1948 \text { and } 1974 & 13\end{array}$

$\begin{array}{ll}\text { The reorganisation of the NHS } & 19\end{array}$

The reorganised National Health Service $\quad 21$

$\begin{array}{ll}\text { Conclusion } & 24\end{array}$

2 Health Policy under Thatcher and Major 27

$\begin{array}{ll}\text { Increasing NHS efficiency } & 27\end{array}$

Making the NHS businesslike $\quad 29$

Dealing with the funding crisis $\quad 32$

$\begin{array}{ll}\text { Working for Patients } & 35\end{array}$

The reform of primary care and community care $\quad 38$

Implementing the reforms $\quad 39$

The impact of the reforms $\quad 45$

$\begin{array}{ll}\text { Streamlining the structure } & 48\end{array}$

$\begin{array}{ll}\text { Conclusion } & 49\end{array}$

3 New Labour and the NHS 51

The inheritance $\quad 51$

$\begin{array}{ll}\text { The new NHS } & 54\end{array}$

$\begin{array}{ll}\text { The new structure } & 57\end{array}$ 
$\begin{array}{ll}\text { Implementation } & 61\end{array}$

$\begin{array}{ll}\text { Integrated care } & 64\end{array}$

$\begin{array}{ll}\text { The comprehensive spending review } & 66\end{array}$

$\begin{array}{ll}\text { Northern Ireland, Scotland and Wales } & 67\end{array}$

$\begin{array}{ll}\text { Conclusion } & 70\end{array}$

4 Contemporary Issues in Health Policy 72

$\begin{array}{ll}\text { The growth of NHS expenditure } & 72\end{array}$

Raising and spending money in the NHS $\quad 76$

$\begin{array}{lr}\text { Public health and health improvement } & 80\end{array}$

$\begin{array}{ll}\text { Health care } & 84\end{array}$

$\begin{array}{ll}\text { Health and social care } & 90\end{array}$

Priority-setting $\quad 93$

$\begin{array}{lr}\text { Conclusion } & 96\end{array}$

5 The Policy-making Process in Central Government 97

$\begin{array}{ll}\text { What is policy? } & 97\end{array}$

The policy process $\quad 99$

Limits of the systems model 101

$\begin{array}{ll}\text { British central government } & 102\end{array}$

$\begin{array}{ll}\text { Parliament } & 104\end{array}$

$\begin{array}{ll}\text { The Prime Minister and Cabinet } & 106\end{array}$

$\begin{array}{ll}\text { Ministers and civil servants } & 109\end{array}$

Relationships between departments $\quad 111$

$\begin{array}{ll}\text { Outside interests } & 114\end{array}$

$\begin{array}{ll}\text { Pluralism or corporatism? } & 115\end{array}$

$\begin{array}{ll}\text { Conclusion } & 118\end{array}$

6 Making and Changing Health Policy 120

$\begin{array}{lr}\text { The Department of Health } & 120\end{array}$

$\begin{array}{ll}\text { The policy community } & 126\end{array}$

$\begin{array}{lr}\text { The sources of policy inputs } & 129\end{array}$

Policy analysis in the Department 142

$\begin{array}{ll}\text { Back to management } & 145\end{array}$

$\begin{array}{ll}\text { Conclusion } & 150\end{array}$

7 Implementing Health Policy 152

The management of the NHS $\quad 152$

$\begin{array}{ll}\text { NHS Executive regional offices } & 153\end{array}$

$\begin{array}{lr}\text { Health authorities } & 155\end{array}$

$\begin{array}{lr}\text { NHS trusts } & 158\end{array}$

Primary care trusts $\quad 159$

$\begin{array}{lr}\text { Special health authorities } & 160\end{array}$

$\begin{array}{ll}\text { The role of the } \mathrm{DH} & 160\end{array}$ 
Professional influences on policy implementation 166

$\begin{array}{lr}\text { Policy-making in NHS bodies } & 170\end{array}$

$\begin{array}{ll}\text { Conclusion } & 174\end{array}$

8 Monitoring and Evaluating Health Policy 176

$\begin{array}{ll}\text { The audit explosion } & 176\end{array}$

Health improvement $\quad 184$

Access to health care $\quad 191$

The NHS in the international context 197

Conclusion $\quad 202$

9 Power in Health Services $\quad 203$

$\begin{array}{ll}\text { Marxist approaches } & 203\end{array}$

$\begin{array}{ll}\text { Pluralism } & 204\end{array}$

Structuralist approaches 205

$\begin{array}{ll}\text { Concepts of health } & 207\end{array}$

Power, interests and ideology 209

$\begin{array}{ll}\text { Theories and practice } & 212\end{array}$

$\begin{array}{ll}\text { Conclusion } & 216\end{array}$

$\begin{array}{ll}\text { Guide to Further Reading } & 218\end{array}$

$\begin{array}{ll}\text { Bibliography } & 221\end{array}$

$\begin{array}{ll}\text { Index } & 231\end{array}$ 


\section{List of Figures and Tables}

\section{Figures}

1.1 The structure of the NHS, 1948-74 13

1.2 The structure of the NHS, 1974-82 20

1.3 The structure of the NHS, 1982-91 24

2.1 Hospital and community health services: trends in spending, targets and shortfalls 33

2.2 The structure of the NHS in England, 1991-96 40

2.3 The structure of the NHS in England, 1996-99 47

3.1 The structure of the new NHS 58

3.2 Levels of primary care groups $\quad 59$

3.3 A framework for quality 63

3.4 The structure of the NHS in Scotland 68

4.1 Cost of NHS as percentage of GDP, 1949-98 74

4.2 International comparison of expenditures on health care, 1996

4.3 Sources of NHS finance, 1997-98 77

4.4 Distribution of NHS budget, 1997-98 77

4.5 Distribution of hospital and community health services expenditure, 1995-96 78

4.6 Distribution of family health services expenditure, 1996-97 78

4.7 Distribution of health and community health services expenditure by age group, 1995-96 79

4.8 Expectation of life at birth, EU, 1995

5.1 A simplified model of a political system 100

6.1 Structure of the Department of Health 121

6.2 Structure of the NHS Executive 123

7.1 NHS Executive regional office boundaries from 1 April $1999 \quad 154$

8.1 Percentage survival to 1991 of children born since 1950, England and Wales

8.2 Prevalence of reported limiting long-standing illness by socioeconomic group, and by age group, Great Britain, $1994 \quad 188$

8.3 Waiting lists in England and Wales, 1948-96 196

8.4 Health in Europe 198 


\section{Tables}

2.1 Background of general managers, $1986 \quad 31$

2.2 The implementation of GP fundholding and NHS trusts 41

$\begin{array}{lll}4.1 & \text { NHS expenditure UK, 1949-96 } & 73\end{array}$

4.2 NHS directly employed staff, 1996, England (WTEs) 79

4.3 A contract for health 83

4.4 The Patient's Charter 86

$\begin{array}{ll}\text { 8.1 NHS performance assessment framework } & 181\end{array}$

8.2 Life expectancy, England and Wales, 1841-1991 185

8.3 Age-specific mortality rates, by social class, men aged 20-64, $\begin{array}{ll}\text { all causes, England and Wales, 1991-93 } & 187\end{array}$

8.4 Comparison of mortality rates per million population in England and Wales in 1950 and $1994 \quad 190$

8.5 Percentage shares of NHS expenditure standardised for need, 1974-87 


\section{Acknowledgements}

The author and publishers would like to thank the following who have kindly given permission for the use of copyright material: The University of Chicago Press for a diagram from David Easton, A Systems Analysis of Political Life, 1965; The King's Fund for a figure from Health Finance: Assessing the Options, 1988; The Nuffield Trust for a table from Who Pays For and Who Gets Health Care?, 1998; The Economist for a figure from the issue of 12 December 1998; Crown Copyright material is reproduced with the permission of the Controller of Her Majesty's Stationery Office (from Department of Health, The Government's Expenditure Plan 1998-99: Departmental Report; Secretary of State for Health, The New NHS: Modern, Dependable; Secretary of State for Health, Our Healthier Nation; Secretary of State for Health, A First Class Service; Secretary of State for Scotland, Designed to Care; F. Drever and M. Whitehead, Health Inequalities; B. Botting, The Health of Our Children; J. Charlton and M. Murphy, The Health of Adult Britain 1841-1994).

Every effort has been made to contact all the copyright-holders, but if any have been inadvertedly ommitted the publishers will be pleased to make the necessary arrangement at the earliest opportunity. 


\section{Preface to the Fourth Edition}

This book was originally based on undergraduate and postgraduate courses I taught at Bristol University. The first edition benefited from the comments and suggestions of the students who followed those courses. I am particularly grateful to Laurie McMahon and Andrew Wall for their insights, gained during the first intake of the MSc in Public Policy Studies run by the School for Advanced Urban Studies at Bristol. I would also like to thank former colleagues at the School who commented on draft chapters, most notably Robin Hambleton, Michael Hill, Robin Means, Randall Smith and David Towell. Special mention should also be made of Ken Judge, with whom I jointly taught an undergraduate course in health policy. As editor of the series, 'Studies in Social Policy', in which the first two editions appeared, Ken encouraged me to write Health Policy in Britain, and as always was a constructive and critical collaborator.

The fourth edition is based on the same structure as earlier editions but has been completely revised and updated to take account of developments in health services and health policy in the 1990s. I have benefited from the advice and comments of a number of people in the Department of Health and the NHS as well as colleagues at the Health Services Management Centre at the University of Birmingham. I would particularly like to mention the assistance provided by Brigit Ayling and her colleagues in the Centre's library; the support of my assistant, Anne van der Salm; and also the work of Debbie Styer, who incorporated my new text with the original, with the lastminute help of Sue Alleyne and other colleagues. My publisher, Steven Kennedy, was even more patient on this occasion than previously.

Last but not least, I would like to thank Ioanna Burnell for her continuing support. The distractions that writing (and revising) a book inevitably creates intrudes into home life. Once again, I am pleased to dedicate the book to Ioanna.

I alone am responsible for the final text. 


\section{Abbreviations}

$\begin{array}{ll}\text { AHA } & \text { Area Health Authority } \\ \text { ASH } & \text { Action on Smoking and Health } \\ \text { BMA } & \text { British Medical Association } \\ \text { CHC } & \text { Community Health Council } \\ \text { CHI } & \text { Commission for Health Improvement } \\ \text { CIP } & \text { Cost Improvement Programme } \\ \text { CMO } & \text { Chief Medical Officer } \\ \text { CPRS } & \text { Central Policy Review Staff } \\ \text { CSR } & \text { Comprehensive Spending Review } \\ \text { DCMO } & \text { Deputy Chief Medical Officer } \\ \text { DGH } & \text { District General Hospital } \\ \text { DGM } & \text { District General Manager } \\ \text { DH } & \text { Department of Health } \\ \text { DHA } & \text { District Health Authority } \\ \text { DHSS } & \text { Department of Health and Social Security } \\ \text { DMT } & \text { District Management Team } \\ \text { DMU } & \text { Directly Managed Units } \\ \text { FHSA } & \text { Family Health Services Authority } \\ \text { FPC } & \text { Family Practitioner Committee } \\ \text { FPS } & \text { Family Practitioner Services } \\ \text { GHS } & \text { General Household Survey } \\ \text { GDP } & \text { Gross Domestic Product } \\ \text { GP } & \text { General Practitioner } \\ \text { HAS } & \text { Health Advisory Service } \\ \text { HCHS } & \text { Hospital and Community Health Services } \\ \text { HImP } & \text { Health Improvement Programme } \\ \text { HMC } & \text { Hospital Management Committee } \\ \text { HMO } & \text { Health Maintenance Organisation } \\ \text { JCC } & \text { Joint Consultative Committee } \\ \text { MAS } & \text { Management Advisory Service } \\ \text { MPC } & \text { Medical Practices Committee } \\ \text { NAHA } & \text { National Association of Health Authorities } \\ \text { NAHAT } & \text { National Association of Health Authorities and Trusts } \\ \text { NAO } & \text { National Audit Office } \\ \text { NICE } & \text { National Institute for Clinical Excellence } \\ \text { NHS } & \text { National Health Service } \\ \text { NHSME } & \text { National Health Service Management Executive } \\ & \\ & \end{array}$


NHST National Health Service Trusts

OECD Organisation for Economic Cooperation and Development

OHE Office of Health Economics

OPCS Office of Population, Censuses and Surveys

PACT Prescribing Analysis and Cost System

PCGs Primary Care Groups

PESC Public Expenditure Survey Committee

QALY Quality Adjusted Life Year

RAWP Resource Allocation Working Party

RCP Royal College of Physicians

RGM Regional General Manager

RHA Regional Health Authority

RHB Regional Hospital Board

RL Regional Liaison

SHA Special Health Authority

SMR Standardised Mortality Ratio 